Anugrahadi, et al/Jurnal Ekonomi Syariah Teori dan Terapan Vol. 6 No. 11 November 2019: 2252-2271; MENGETAHUI PENGARUH KINERJA ISLAM TERHADAP MOTIVASI ISLAM, KOMITMEN ISLAM, DAN PELATIHAN ISLAM PADA KARYAWAN PT. ASURANSI TAKAFUL KELUARGA DI JAKARTA

\title{
MENGETAHUI PENGARUH KINERJA ISLAM TERHADAP MOTIVASI ISLAM, KOMITMEN ISLAM, DAN PELATIHAN ISLAM PADA KARYAWAN PT. ASURANSI TAKAFUL KELUARGA DI JAKARTA ${ }^{1}$
}

\author{
Yoga Dwi Anugrahadi \\ Departemen Ekonomi Syariah - Fakultas Ekonomi dan Bisnis - Universitas Airlangga \\ Email: yoga.anugrahadi@gmail.com
}

Ari Prasetyo

Departemen Ekonomi Syariah - Fakultas Ekonomi dan Bisnis - Universitas Airlangga Email: ari_feunair@yahoo.co.id

\begin{abstract}
:
The bacground of this research is that employees who work at Islamic Financial Institutions (IFIs) get problem both in quantitiy and quality of human resources. This study aims to analyse variables of human resource in Islamic perspective, such as Islamic motivation, Islamic commitment, Islamic training, and Islamic performance. This study used total 64 employees for random sampling observations and using Ordinary Least Square Regression analysis model with SPSS software. Data collection using questionnaire with Linkert scale 1 to 4. This study find partially that Islamic motivation and Islamic commitment are negatively related to Islamic performance, but Islamic training significantly related to Islamic performance. But, this research find that three variables simultanously related together to Islamic performance. Although Islamic training just has influence Islamic performance, therefore Islamic motivation and commitment have positive value in linier regression but in small value.
\end{abstract}

Keywords: Islamic motivation, Islamic commitment, Islamic training, PT. Family Takaful Insurance

\section{PENDAHULUAN}

\section{Latar Belakang}

Sumber daya manusia merupakan aset utama dalam perusahaan atau organisasi. Menurut pendapat Mathis dan Jackson (2015:1) bahwa peran strategis sumber daya manusia menekankan bahwa orang-orang di organisasi adalah sumber daya penting dan juga investasi perusahaan yang besar. Sumber daya Manusia dipandang semakin besar

Seiring berjalannya waktu muncul permasalahan dasar yang terdapat pada lembaga keuangan syariah yaitu masalah kuantitas dan kualitas sumber daya manusianya. Dimana seharusnya sumber daya manusia yang terdapat pada lembaga keuangan syariah seharusnya mempunyai penguasaan ilmu ekonomi dalam bidang syariah, kenyataannya sumber daya yang terdapat pada lembaga keuangan syariah masih banyak yang belum menguasai hal-hal yang bersifat syariah.

Dari data tahun 2011 salah satu artikel berdasarkan data Bank Indonesia pertumbuhan lembaga keuangan di Indonesia itu mencapai $40 \%$ tiap tahunnya, sementara pertumbuhan pegawai syariah rata-rata sekitar 24,25\% sedangkan pertumbuhan gerai lembaga kevangan syariah rata-rata sekitar 29,25\%

${ }^{1}$ Jurnal ini merupakan bagian dari skripsi yang ditulis oleh Yoga Dwi Anugrahadi, NIM: 041311433057, yang diuji pada 5 Januari 2018. 
Anugrahadi, et al/Jurnal Ekonomi Syariah Teori dan Terapan Vol. 6 No. 11 November 2019: 2252-2271; MENGETAHUI PENGARUH KINERJA ISLAM TERHADAP MOTIVASI ISLAM, KOMITMEN ISLAM, DAN PELATIHAN ISLAM PADA KARYAWAN PT. ASURANSI TAKAFUL KELUARGA DI JAKARTA

dalam kurun waktu yang sama. Dengan terbatasnya ketersediaan sumber daya manusia yang memadai dalam menguasai tentang ekonomi dan syariah, maka lembaga kevangan syariah lebih merekrut karyawan yang dari lembaga kevangan umum. Dengan begitu kuantitas dan kualitas di lembaga kevangan syariah menjadi permasalahan dasar yang terdapat pada perusahaan. (www.beritasatu.com, 2018)

Membangun sumber daya manusia yang baik untuk lembaga keuangan syariah maka dibutuhkan kelompok yang profesional dalam mengorganisasi perusahaan dengan baik. Kualifikasi sumber daya manusia yang baik seperti sifat Rasulullah SAW yaitu siddiq, amanah, tabligh, fathanah, dan istiqamah. Berdasarkan tingkat pemahaman ekonomi dan syariah ada tiga klasifikasi sumber daya manusia yaitu: (1) spesialis terhadap ilmu syariah namun tidak memahami ilmu ekonomi, (2) spesialis ilmu ekonomi tetapi hanya memahami ilmu syariah, (3) spesialis ilmu ekonomi dan juga spesialis ilmu syariah.

Firman Allah SWT di Al Qur'an Surat At Tin Ayat 4:

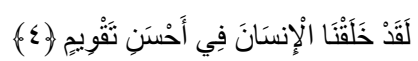

Laqad khalaqnal-insãna fî ahsani taqwîm.

Artinya:Sesungguhnya, kami telah ciptakan manusia dalam bentuk sebaikbaiknya. (QS At Tin: 4) (Depag Rl, 2017)

Hadist tentang menginginkan kebahagiaan dunia dan akhirat wajib dengan ilmu:

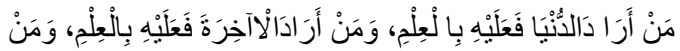

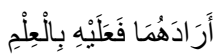

Man aroda dunya fa'alaihi bil 'ilmi, man arodal akhiroh fa'alaihi bil ilmi, wa man aroda huma fa'alaihi bil 'ilmi.

Artinya:Barang siapa yang menghendaki kehidupan dunia maka wajib baginya memiliki ilmu, dan barang siapa yang menghendaki kehidupan Akherat, maka wajib baginya memiliki ilmu, dan barang siapa menghendaki keduanya maka wajib baginya memiliki ilmu. (HR. Turmudzi) (Baqi, 2010:76)

Arti dari salah satu surat dari Al Qur'an dan potongan hadist tersebut menyatakan bahwa seorang manusia terlahir didunia dengan bentuk yang sebaik-baiknya yang memiliki akal dan hawa nafsu, dengan adanya itu manusia harus dapat menentukan tujuan hidupnya sendiri. Dengan dibekali kemampuan yang baik dari Allah manusia itu wajib memiliki ilmu, akan tetapi dalam menjalankan kewajibannya itu jangan lupa mencari ilmu yang sudah diatur oleh Allah yang sudah terdapat pada Al Qur'an maupun Hadist. Dengan memiliki ilmu dunia yang baik dan benar dapat menjalankan kegiatan dan mengorganisasi dengan sebaik-baiknya untuk mencapai sebuah tujuan, karena pertama kalinya manusia lahir itu tujuannya untuk menjadi khalifah dibumi untuk memelihara dan menjaga kehidupan.

Sumber daya manusia dalam organisasi sangat strategis dan 
Anugrahadi, et al/Jurnal Ekonomi Syariah Teori dan Terapan Vol. 6 No. 11 November 2019: 2252-2271; MENGETAHUI PENGARUH KINERJA ISLAM TERHADAP MOTIVASI ISLAM, KOMITMEN ISLAM, DAN PELATIHAN ISLAM PADA KARYAWAN PT. ASURANSI TAKAFUL KELUARGA DI JAKARTA

menentukan, bahkan keberhasilan organisasi untuk mencapai tujuan yang ditetapkan itu dipengaruhi oleh faktor sumber daya manusia. Menurut Sinaga (2015:2) komponen dalam rangka pemberdayaan sumber daya manusia yaitu : kemampuan karyawan, motivasi, dukungan terhadap karyawan, kepercayaan pada karyawan, komitmen serta tanggung jawab dalam pekerjaan, dan penempatan karyawan.

Menurut beberapa survei lembaga penelitian tentang sumber daya manusia yang terdapat pada perusahaan yang pertama yaitu data survei dari tower watson tahun 2014 mengungkapkan bahwa banyak perusahaan di Indonesia cenderung meninggalkan perusahaan dalam kurun waktu dua tahun sekitar $66 \%$, sedangkan sisanya sekitar $34 \%$ karyawan tetap bertahan diperusahaan. Satu survei lagi dari lembaga yang sama tentang perusahaan menyatakan bahwa lebih dari $20 \%$ mengalami kesulitan dalam merekrut dan mempertahankan tenaga kerja yang kompeten.

$\begin{array}{llr}\text { Data } & \text { tersebut } & \text { merupakan } \\ \text { cerminan } & \text { komponen } & \text { dalam } \\ \text { pemberdayaan } & \text { sumber daya manusia } \\ \text { yaitu komitmen. Menurut pendapat dari } \\ \text { Mowday } & \text { (2015:10) } & \text { komitmen }\end{array}$
organisasional merupakan perilaku yang dapat digunakan untuk menilai kecenderungan karyawan untuk bertahan sebagai anggota organisasi. Begitu juga pendapat dari salah satu pakar tentang komitmen dalam perspektif syariah, yaitu komitmen adalah keyakinan yang mengikat sedemikian kukuhnya sehingga membelenggu seluruh hati nuraninya dan kemudian menggerakkan perilaku menuju arah tertentu yang diyakininya (Tasmara, 2008:1).

Menurut pendapat yang lainnya dari Amin (2010:120) Komitmen kerja Islam adalah kesediaan dan kerelaan bekerja dengan menepati segala ketentuan kerja dalam ajaran agama. Komitmen sangat penting untuk dimiliki oleh setiap muslim dalam melakukan sesuatu yang baik. Komitmen dapat diartikan sebagai pengabdian, pengabdian yang baik adalah mengabdi kepada Allah SWT. firman Allah SWT dalam surat Adz Dzariyaat ayat 56 :

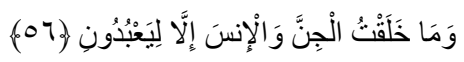

Wamã khalaqtul-jinna wal-insa illã liya'budûn.

Artinya:Dan aku tidak menciptakan jin dan manusia melainkan supaya mereka mengabdi kepadaku. (QS Adz Dzariyaat:56) (Depag Rl, 2017)

Data survei yang kedua yaitu dari lembaga survei jobstreet Indonesia pada bulan juni-juli 2016 mengenai sumber daya manusia yang terdapat pada perusahaan di Indonesia mengungkapkan bahwa motivasi kerja karyawan mengalami kinerja yang turun, salah satu surveinya mengenai tidak bahagianya karyawan ditempat kerja sekitar 33,4\%.

Menurut mathis dan Jackson (2015:20) motivasi adalah keinginan dalam diri seseorang yang menyebabkan 
Anugrahadi, et al/Jurnal Ekonomi Syariah Teori dan Terapan Vol. 6 No. 11 November 2019: 2252-2271; MENGETAHUI PENGARUH KINERJA ISLAM TERHADAP MOTIVASI ISLAM, KOMITMEN ISLAM, DAN PELATIHAN ISLAM PADA KARYAWAN PT. ASURANSI TAKAFUL KELUARGA DI JAKARTA

orang tersebut bertindak, orang bertindak karena satu alasan yaitu untuk mencapai tujuan. Jadi motivasi merupakan salah satu faktor bagi seseorang dalam bekerja, dalam perspektif Islam motivasi adalah terkait pekerjaan yang berasal dari hubungan seorang karyawan dengan tuhannya (Rahman, 1995:13). Islam memandang motivasi sebagai sesuatu yang penting, seperti firman Allah SWT dalam surat Al Baqarah ayat 148:

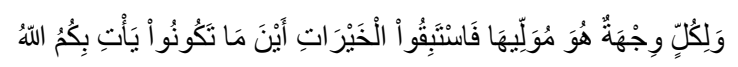

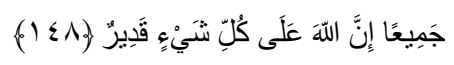

Wa li kulliw wijhatun huwa muwallihã fastabiqul-khairãt, aina mã takûnû ya'ti bikumullãhu jamîã innallãha 'alã kulli syai'in qadîr.

Artinya:Dan bagi tiap-tiap umat ada kiblatnya (sendiri) yang ia menghadap kepadanya. Maka berlomba-lombalah (dalam membuat) kebaikan. Di mana saja kamu berada pasti Allah akan mengumpulkan kamu sekalian (pada hari kiamat). Sesungguhnya Allah Maha Kuasa atas segala sesuatu. (QS Al Baqarah:148) (Depag RI, 2017)

Umat manusia seharusnya
menyadari bahwa salah satu kewajibannya di muka bumi adalah mencari karunia Allah SWT. Karunia Allah SWT atau rezeki bisa diperoleh ketika melakukan pencarian, usaha atau bekerja. Rezeki memang telah ditentukan oleh Allah SWT, tetapi wajib mencari dan berusaha mendapatkannya. Allah SWT berfirman dalam Surat Al Mulk ayat 15:

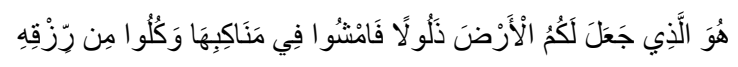

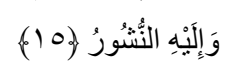

Huwal-lazî ja'ala lakumul-arda zalûlan famsyû fî manãkibihã wa kulû mir rizqih, wa ilaihin-nusyûr.

Artinya:Dialah Yang menjadikan bumi itu mudah bagi kamu, maka berjalanlah di segala penjurunya dan makanlah sebahagian dari rezeki-Nya. Dan hanya kepada-Nya-lah kamu (kembali setelah) dibangkitkan. (QS Al Mulk:15) (Depag RI, 2017)

Data survei yang ketiga yaitu dari lembaga survei asian enterprise report tahun 2016 mengungkapkan bahwa perusahaan di Indonesia memandang pentingnya investasi, survei mengatakan bahwa investasi dalam hal pelatihan karyawan sekitar $37 \%$ dan pengadaan alat-alat perusahaan sekitar $28 \%$. Dengan begitu perusahaan pasti menginginkan sumber daya manusia dapat bekerja lebih efektif, efisien, dan mempunyai prestasi kerja yang baik, sehingga perusahaan dapat mencapai tujuan dan meningkatkan nilai perusahaan secara optimal.

Pada dasarnya pelatihan itu merupakan proses yang berlanjut dan bukan proses sesaat saja, munculnya kondisi baru dalam dunia bisnis sangat mendorong pemimpin organisasi untuk terus memperhatikan dan menyusun program pelatihan yang kontinyu serta semantap mungkin (Sumidjo, 2015:30).

Untuk menjalankan program pelatihan diperlukan suatu perencanaan yang baik, sistematis dan terarah sehingga hasil dari program ini dapat memberi 
Anugrahadi, et al/Jurnal Ekonomi Syariah Teori dan Terapan Vol. 6 No. 11 November 2019: 2252-2271; MENGETAHUI PENGARUH KINERJA ISLAM TERHADAP MOTIVASI ISLAM, KOMITMEN ISLAM, DAN PELATIHAN ISLAM PADA KARYAWAN PT. ASURANSI TAKAFUL KELUARGA DI JAKARTA

masukan positif bagi perusahaan. Selain itu karena biaya untuk melakukan program pelatihan cukup besar, maka program pelatihan karyawan harus berhasil dan berpengaruh positif terhadap prestasi kerja karyawan agar biaya yang dikeluarkan tidak terbuang percuma. Firman Allah SWT dalam surat Al Qashas ayat 26 :

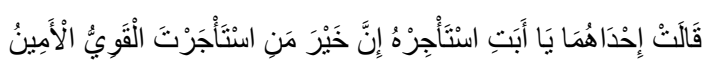

Qãlat iḥdãhumã yã abatista'jirhu inna khaira manista'jartal-qawiyyul-amîn.

Artinya:Salah seorang dari kedua wanita itu berkata: ya bapakku ambillah ia sebagai orang yang bekerja (pada kita), karena sesungguhnya orang yang paling baik yang kamu ambil untuk bekerja (pada kita) ialah orang yang kuat lagi dapat dipercaya. (QS Al Qashas:26) (Depag RI, 2017)

Berkaitan dengan ayat diatas jelas bahwa seorang karyawan dipilih berdasarkan kekuatan fisik dan mental dalam menghadapi tugas pekerjaan yang dibebankan kepadanya serta dapat dipercaya. Kekuatan yang seperti itu dapat dihasilkan melalui pelatihan yang secara teratur diberikan kepada karyawan guna memperbaiki kinerjanya,

Dengan memiliki kualitas dan kuantitas sumber daya manusia yang baik diharapkan membantu perusahaan untuk mencapai tujuannya, tujuan perusahaan salah satunya yaitu kinerja perusahaan yang baik seperti pendapat dari Costello (2015:40) yang berbunyi manajemen kinerja merupakan dasar dan kekuatan pendorong yang berada di belakang semua keputusan organisasi, usaha kerja dan alokasi sumberdaya.

Wirawan (2015:41) menjelaskan kinerja adalah keluaran yang dihasilkan oleh fungsi-fungsi atau indikator-indikator suatu pekerjaan atau suatu profesi dalam waktu tertentu. Dalam pandangan Islam, Tasmara (2008:9) menjelaskan bahwa kinerja adalah hasil dari suatu upaya yang bersungguh-sungguh dengan mengerahkan seluruh asset, pikir, dzikirnya untuk mengaktualisasikan diri sebagai hamba Allah SWT yang harus menundukan dunia dan menempatkan dirinya sebagai bagian dari masyarakat yang terbaik.

Dalam penjelasan tersebut bahwa sebagai seorang karyawan muslim yang ingin menghasilkan kinerja Islam diperlukan kesungguhan dalam proses bekerja serta berfokus pada pencapaian dunia dan akhirat. Hasil dari seorang karyawan dalam mewujudkan kinerja Islam tersebut menunjukkan semangat bekerja kepada organisasi dan yang paling utama yakni sikap patuh dan taat kepada Allah SWT.

Supaya mencapai kinerja yang baik, seorang muslim dituntut untuk bersungguh-sungguh, seorang muslim dapat menunjukkan jati dirinya sebagai masyarakat yang terbaik yang dapat bermanfaat bagi lingkungannya. Seorang muslim yang memiliki pemahaman bahwa bekerja merupakan salah satu ibadah 
Anugrahadi, et al/Jurnal Ekonomi Syariah Teori dan Terapan Vol. 6 No. 11 November 2019: 2252-2271; MENGETAHUI PENGARUH KINERJA ISLAM TERHADAP MOTIVASI ISLAM, KOMITMEN ISLAM, DAN PELATIHAN ISLAM PADA KARYAWAN PT. ASURANSI TAKAFUL KELUARGA DI JAKARTA

akan selalu terpacu semangatnya untuk mencapai kinerja optimal.

Masyarakat dunia akan selalu berinovasi, seperti berkembangnya berbagai kegiatan seperti ekonomi, teknologi, gaya hidup, dan lain-lain yang mengikuti keinginan manusia. Walaupun begitu manusia selalu akan menghadapi berbagai resiko yang mereka hadapi. Resiko bisa datang secara langsung maupun tidak langsung ataupun resiko yang bersifat material maupun spiritual tergantung situasi yang mereka hadapi. Dengan berbagai masalah seperti itu manusia sekarang mulai berpikir akan resiko yang mereka hadapi, dengan berbagai masalah itu manusia sekarang melakukan perjanjian timbal balik yang senilai. Dimana ada yang membayar premi dan ada juga yang mempunyai kewajiban mengganti kerugian seseorang, begitulah latar belakang adanya asuransi.

Dengan peran asuransi dalam memberikan perlindungan terhadap resiko yang akan dihadapi oleh masyarakat, sehingga permintaan kebutuhan terhadap jaminan asuransi mulai bisa menumbuhkan pertumbuhan ekonomi. Dengan adanya permintaan asuransi yang meningkat maka perusahaan asuransi akan terus meningkatkan penawaran kepada investor untuk berinvestasi di jasa asuransi.

Dengan dibantu data tahun 2016 dari Asosiasi Asuransi Syariah Indonesia (AASI) terdapat 53 perusahaan asuransi yang terdiri dari asuransi jiwa terbagi menjadi 5 asuransi jiwa umum dan 19 UUS, asuransi umum terbagi menjadi 4 asuransi umum dan 21 UUS, 3 reasuransi, dan 1 asuransi pembiayaan syariah serta data dari OJK per Maret 2016 pertumbuhan aset asuransi syariah saat berada di angka 21,69 persen, ini menandakan bahwa asuransi syariah bisa bersaing dengan asuransi konvensional. (www.aasi.or.id, 2017)

Dengan dilihat dari data Badan Pusat Statistika tahun 2017 jasa keuangan dan asuransi merupakan sektor pertumbuhan industri mampu tumbuh $8,87 \%$ nilai pertumbuhan tertinggi di Indonesia dari sektor yang lainnya seperti jasa informasi komunikasi, jasa pendidikan kesehatan, jasa transportasi, dan jasa perusahaan. Melihat data seperti itu peneliti menggunakan sampel di salah satu perusahaan asuransi dikarenakan jasa asuransi merupakan salah satu sektor pertumbuhan tertinggi di Indonesia. (www.kompas.com, 2018)

Penelitian ini akan dilakukan di Perusahaan Asuransi Takaful Keluarga yang bertempat di Jakarta. Di dalam melaksanakan misinya tersebut Perusahaan Asuransi Takaful Keluarga membutuhkan sumber daya manusia yang berkualitas. Sumber daya manusia yang berkualitas tidak hanya memiliki banyak pengetahuan terkait dengan produk yang ditawarkan melainkan etika juga diperlukan.

Berdasarkan uraian di atas, peneliti tertarik untuk membahas dan meneliti 
Anugrahadi, et al/Jurnal Ekonomi Syariah Teori dan Terapan Vol. 6 No. 11 November 2019: 2252-2271; MENGETAHUI PENGARUH KINERJA ISLAM TERHADAP MOTIVASI ISLAM, KOMITMEN ISLAM, DAN PELATIHAN ISLAM PADA KARYAWAN PT. ASURANSI TAKAFUL KELUARGA DI JAKARTA

lebih dalam tentang masalah yang terdapat pada perusahaan. Penelitian ini berjudul "Pengaruh Motivasi Islam, Komitmen Islam, dan Pelatihan terhadap Kinerja Islam Pada Karyawan PT. Asuransi Takaful Keluarga di Jakarta". Diharapkan dengan dilakukannya penelitian ini akan diketahui seberapa besar pengaruh motivasi Islam, komitmen Islam, dan pelatihan Islam terhadap kinerja Islam pada perusahaan.

\section{Rumusan Masalah}

Berdasarkan uraian pada latar belakang diatas, dapat dirumuskan bahwa masalah yang akan diteliti adalah:

1. Apakah motivasi Islam, komitmen Islam, dan pelatihan Islam berpengaruh secara parsial terhadap kinerja Islam?

2. Apakah motivasi Islam, komitmen Islam, dan pelatihan Islam berpengaruh secara simultan terhadap kinerja Islam?

\section{Tujuan Penelitian}

Berdasarkan rumusan masalah di atas, maka tujuan penelitian ini adalah sebagai berikut :

1. Untuk mengetahui pengaruh secara parsial pada variabel motivasi Islam, komitmen Islam, dan pelatihan Islam terhadap kinerja Islam.

2. Untuk mengetahui pengaruh secara simultan pada variabel motivasi Islam, komitmen Islam, dan pelatihan Islam terhadap kinerja Islam.

\section{LANDASAN TEORI}

\section{Motivasi Islam}

Motivasi merupakan hasrat
didalam diri seseorang yang

menyebabkan orang tersebut melakukan tindakan. Motivasi diartikan sebagai keadaan dalam pribadi seseorang yang mendorong keinginan individu untuk melakukan kegiatan-kegiatan tertentu guna mencapai tujuan (Handoko, 2015:22).

Mencari nafkah dalam Islam adalah sebuah kewajiban. Islam adalah agama yang fitrah, yang sesuai kebutuhan manusia, diantaranya adalah kebutuhan fisik. Salah satu cara memenuhi kebutuhan fisik itu ialah dengan bekerja. Motivasi dalam Islam bukanlah untuk mengejar hidup hedonisme, bukan juga untuk status, apalagi mengejar kekayaan dengan segala cara. dengan demikian motivasi Islam bukan hanya untuk memenuhi nafkah semata tetapi sebagai kewajiban beribadah kepada Allah SWT setelah ibadah fardhu lainnya.

Motivasi Islam adalah terkait pekerjaan yang berasal dari hubungan seorang karyawan dengan tuhannya (Rahman, 1995:13). Selama ini banyak orang bekerja untuk mengejar materi belaka demi kepentingan duniawi, mereka tak sedikitpun mempedulikan kepentingan akhirat kelak. Oleh karena itu sebaiknya pekerja perlu memiliki motivasi yang dapat memberikan kepribadian yang baik dan dibenarkan oleh Islam.

\section{Komitmen Islam}

Komitmen adalah keyakinan yang mengikat sedemikian kukuhnya sehingga membelenggu seluruh hati nuraninya dan kemudian menggerakkan perilaku 
Anugrahadi, et al/Jurnal Ekonomi Syariah Teori dan Terapan Vol. 6 No. 11 November 2019: 2252-2271; MENGETAHUI PENGARUH KINERJA ISLAM TERHADAP MOTIVASI ISLAM, KOMITMEN ISLAM, DAN PELATIHAN ISLAM PADA KARYAWAN PT. ASURANSI TAKAFUL KELUARGA DI JAKARTA

menujuh arah tertentu yang diyakininya (Tasmara, 2008:1). Menurut Mowday (2015:10) komitmen organisasional merupakan dimensi perilaku yang dapat digunakan untuk menilai kecenderungan karyawan untuk bertahan sebagai anggota organisasi.

\section{Pelatihan Islam}

Menurut Mangkunegara (2015:43) pelatihan adalah suatu proses pendidikan jangka pendek yang mempergunakan prosedur sistematik dan terorganisir dimana pegawai mempelajari pengetahuan dan keterampilan teknis dalam tujuan terbatas.

Dalam khazanah pengetahuan Islam, secara formal tidak ditemukan secara pasti pelatihan atau pembinaan karyawan di zaman Rasulullah. Dalam sejarah Islam, sejak zaman jahiliyah, telah ada pengambilan budak sebagai buruh, pembantu atau pekerja, walaupun setelah zaman Islam perbudakan mulai dikurangi. Hal ini menandakan adanya tradisi pelatihan dan pembinaan dalam Islam. Ketika Islam datang, Rasulullah membawa sejumlah prinsip etika dan melakukan perubahan radikal dalam memperlakukan pekerja dalam pekerjaan dan pendidikannya. Berdasarkan AI Quran Surat Al Jum'ah ayat 2 :

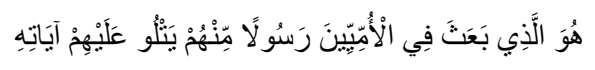

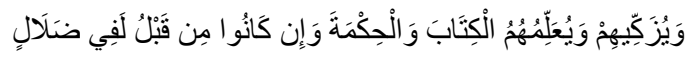

Huwal-lazi ba'asa fil-ummiyyîna rasûlam minhum yatlû 'alaihim ãyãtihî wa yuzakkîhim wa yu'allimuhumul-kitãba wal- hikmata wa in kãnû min qablu lafî dalãlim mubîn.

Artinya: Dialah yang mengutus kepada kaum yang buta huruf (ummi) seorang Rasul di antara mereka, yang membacakan ayat-ayatnya kepada mereka, mensucikan mereka dan mengajarkan mereka kitab dan hikmah (As Sunnah). Dan sesungguhnya mereka sebelumnya benar-benar dalam kesesatan yang nyata. (QS Al Jumu'ah:2) (Depag RI, 2017)

\section{Kinerja Islam}

Menurut Mangkunegara (2015:35) mengatakan bahwa kinerja kerja karyawan adalah hasil kerja secara kualitas dan kuantitas yang dicapai oleh seorang karyawan dalam melaksanakan tugasnya sesuai tanggung jawab yang diberikan kepadanya.

$$
\text { Menurut Zadjuli }
$$

(2004:18) menyatakan Islam menilai kinerja relegius seseorang dapat dilihat dari beberapa indikator antara lain niat bekerjanya adalah karena Allah, dalam bekerja menerapkan kaidah/normal/syariah secara kaffah.

Kinerja menurut Islam seperti firman Allah SWT dalam surat An Najm ayat 39-41 yang berbunyi :

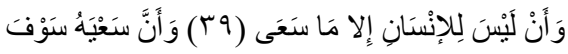

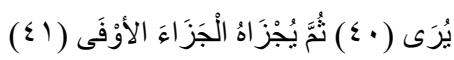

Waal laisa lil-insãni illã mã sa'ã. Waanna sa'yahû saufa yurã. Summa yujzãhuljazã'al-aufã.

Artinya : Dan bahwasanya seorang manusia tiada memperoleh selain apa 
Anugrahadi, et al/Jurnal Ekonomi Syariah Teori dan Terapan Vol. 6 No. 11 November 2019: 2252-2271; MENGETAHUI PENGARUH KINERJA ISLAM TERHADAP MOTIVASI ISLAM, KOMITMEN ISLAM, DAN PELATIHAN ISLAM PADA KARYAWAN PT. ASURANSI TAKAFUL KELUARGA DI JAKARTA

yang telah diusahakannya. Dan bahwasanya usaha itu kelak akan diperlihatkan (kepadanya). Kemudian akan diberi balasan kepadanya dengan balasan yang paling sempurna. (QS An Najm:39-41) (Depag Rl, 2017)

\section{Model Analisis}

Berdasarkan hipotesis diatas, maka dalam penelitian ini digunakan analisis dengan kerangka kerja penelitian untuk menjelaskan hubungan spesifik antara variabel eksogen dan variabel endogen. Model analisis dari penelitian ini adalah sebagai berikut:

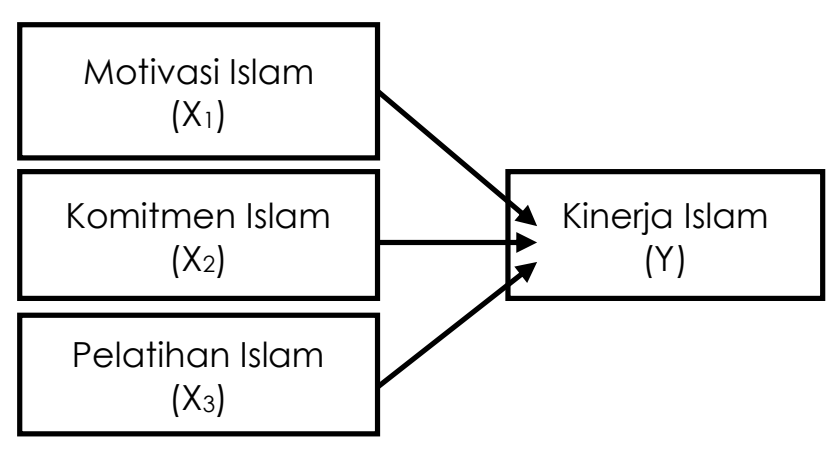

Sumber: Hasil Penelitian, 2017 (diolah)

\section{Gambar 1.}

\section{Model Analisis}

\section{METODE PENELITIAN}

Pendekatan penelitian ini menggunakan pendekatan penelitian yang berjenis kuantitatif. Penelitian kuantitatif adalah penelitian yang menyajikan tahap lebih lanjut dari observasi, muncul peranan teknik-teknik statistik seperti distribusi frekuensi, tendensi sentral, dan dispersi Sugiyono (2012:25). Dengan demikian penelitian ini berusaha menggambarkan fenomena-fenomena dan fakta-fakta yang disajikan dalam angka-angka statistik untuk menjelaskan keadaan sebenarnya.

Setelah data terkumpul, kemudian dianalisis dengan metode regresi linier berganda. Model analisis ini dilakukan untuk mengetahui hubungan variabel eksogen (motivasi Islam, komitmen Islam, dan pelatihan Islam, dan variabel endogen (kinerja Islam).

Berdasarkan variabel-variabel yang digunakan, maka hubungan antar variabel dapat dinyatakan dalam fungsi sebagai berikut:

$Y=f(X)$

Bentuk Persamaan regresi dapat dirumuskan sebagai berikut:

$Y=a+\beta_{1} X_{1}+\beta_{2} X_{2}+\beta_{3} X_{3}+e$

Keterangan:

Dari model analisa regresi linier berganda yang digunakan, terdapat beberapa asumsi klasik yang dapat digunakan untuk mengestimasi hasil agar tidak ada penyimpangan sehingga dapat memberikan informasi yang sesuai dengan data yang tersedia. Asumsi klasik tersebut adalah uji normalitas, uji multikolinieritas, uji autokorelasi, dan uji heteroskedastisitas.

\section{Definisi Operasional}

\section{Motivasi Islam ( $\left.X_{1}\right)$}

1. Rezeki yang halal adalah salah satu dorongan saudara dalam bekerja

2. Saudara merasa ikhlas melakukan semua tugas meskipun pekerjaan itu berat

3. Saudara selalu ingin melakukan yang terbaik dalam pekerjaan 
Anugrahadi, et al/Jurnal Ekonomi Syariah Teori dan Terapan Vol. 6 No. 11 November 2019: 2252-2271;

MENGETAHUI PENGARUH KINERJA ISLAM TERHADAP MOTIVASI ISLAM, KOMITMEN ISLAM, DAN PELATIHAN

ISLAM PADA KARYAWAN PT. ASURANSI TAKAFUL KELUARGA DI JAKARTA

4. Saudara yakin akan kemampuan sendiri untuk melaksanakan tugas dengan baik

5. Saudara bersedia memberi pendapat ketika rekan kerja mengalami kesulitan

6. Saudara merasa puas jika pendapat yang diberikan bisa diterima oleh rekan kerja

7. Saudara bekerja sebagai bentuk pengabdian sebagai hamba Allah

8. Saudara melakukan yang terbaik dalam pekerjaan karena merasa Allah selalu mengawasi perbuatan yang dilakukan

\section{Komitmen Islam $\left(\mathrm{X}_{2}\right)$}

1. Saudara sebagai karyawan bekerja dengan niat karena Allah SWT

2. Saudara sebagai karyawan memiliki tanggung jawab terhadap pekerjaan sebagai bentuk akad yang telah disepakati

3. Saudara sebagai karyawan selalu istiqomah dalam bekerja dengan selalu berusaha yang terbaik di jalan Allah SWT

4. Saudara sebagai karyawan bekerja dengan sungguh-sungguhh dalam menyelesaikan setiap tugas yang ada

5. Saudara sebagai karyawan lebih mengutamakan kepentingan akhirat dari pada kepentingan pribadi

6. Saudara bekerja maksimal untuk mendapatkan nafkah

7. Saudara sebagai karyawan memahami visi dan misi perusahaan

Pelatihan Islam $\left(\mathrm{X}_{3}\right)$
1. Selama pelatihan saudara dapat mengambil ilmu dan materi yang diberikan saat pelatihan

2. Instruktur pelatih yang diberikan perusahaan dapat menarik saudara dalam mengikuti latihan

3. Saudara selalu bersemangat untuk mengikuti pelatihan diberikan

4. Dengan mengikuti pelatihan, apakah saudara dapat meningkatkan prestasi kerjanya

5. Materi yang disiapkan dalam pelatihan lengkap dan memadai sesuai dengan lembaga syariah yang mengikuti hukum Islam

6. Materi yang diberikan dalam pelatihan sesuai dengan tingkat kesulitan dalam bekerja dilembaga syariah

7. Metode pelatihan yang diberikan apakah sudah sesuai dengan ajaran Rasulullah

8. Perusahaan memberikan sosialisasi terhadap pelatihan yang akan diberikan kepada saudara

9. Perusahaan memberikan uang saku untuk meningkatkan minat pelatihan saudara

10.Fasilitas yang disediakan perusahaan dalam pelatihan sesuai dengan yang diharapkan saudara

\section{Kinerja Islam $(Y)$}

1. Hasil usaha yang dilakukan saudara sudah dicapai dengan adanya kemampuan yang dimiliki

2. Hasil kerja saudara sudah dicapai dengan adanya beberapa metode dalam situasi tertentu 
Anugrahadi, et al/Jurnal Ekonomi Syariah Teori dan Terapan Vol. 6 No. 11 November 2019: 2252-2271; MENGETAHUI PENGARUH KINERJA ISLAM TERHADAP MOTIVASI ISLAM, KOMITMEN ISLAM, DAN PELATIHAN ISLAM PADA KARYAWAN PT. ASURANSI TAKAFUL KELUARGA DI JAKARTA

3. Dalam melakukan pekerjaan saudara sudah menggunakan cara-cara yang benar

4. Selama melakukan pekerjaan saudara mendapatkan hasilnya dengan cara yang baik

5. Selama bekerja yang dilakukan saudara apakah sudah memberikan manfaat untuk orang lain

6. Dalam bekerja saudara selalu membantu seseorang ketika mendapatkan masalah

7. Apakah dalam kehidupan saudara sudah mendapatkan kehidupan yang layak

8. Apakah kehidupan saudara sudah mendapatkan kesejahteraan

9. Selama bekerja saudara memperoleh peluang untuk mengembangkan diri

10.Apakah selama bekerja saudara mendapat tambahan ilmu dalam menunjang pekerjaan

11.Apakah kualitas saudara sudah sesuai dengan cara yang diajurkan oleh agama

12.Dalam melakukan pekerjaan dengan cara yang diajurkan oleh agama apakah sudah mendapatkan hasilnya

13.Prestasi yang dicapai oleh Saudara sebagai perwujudan hasil kerja

14.Apakah saudara berusaha dan berkeinginan untuk selalu maju

\section{Populasi dan Sampel}

$$
\text { Menurut Sugiyono }
$$

populasi adalah kelompok elemen (unit analisis) yang lengkap, yang biasanya berupa orang, obyek, transaksi, atau kejadian dimana peneliti tertarik untuk mempelajarinya atau menjadi obyek penelitian. Populasi penulisan ini adalah semua karyawan yang bekerja pada perusahaan asuransi takaful keluarga di kantor pusat Jakarta yang berjumlah 76 karyawan.

Teknik Pengumpulan sampel yang dilakukan pada penelitian ini yaitu dengan pendekatan probability yaitu simple random sampling. Teknik penentuan sampel ini merupakan teknik penentuan sampel yang sederhana karena pengambilan sampel anggota populasi dilakukan secara acak tanpa memperhatikan strata yang ada dalam populasi, Penggunaan teknik ini dilakukan jika anggota populasinya homogen (Iswati, 2009:103).

$$
\text { Menurut Sugiyono (2012:41) }
$$

mengatakan angka yang tepat harus diambil untuk menyakinkan bahwa sampel secara adil mendekati pada parameter populasi. Pada studi penelitian ini, jumlah populasi karyawan perusahaan asuransi takaful keluarga di kantor pusat Jakarta. Maka penelitian ini menerapkan teknik pengambilan sampel melalui pendekatan rumus slovin. Setelah itu didapatkan jumlah sampel yaitu sebanyak 64 responden.

\section{HASIL DAN PEMBAHASAN}

Hasil Uji Regresi Linier Berganda

Uji $\uparrow$

Tabel 1.

Hasil Uji Parsial (Uji †)

\begin{tabular}{|l|l|l|l|}
\hline Variabel & Sig. & Kriteria & Kesimpulan \\
\hline
\end{tabular}


Anugrahadi, et al/Jurnal Ekonomi Syariah Teori dan Terapan Vol. 6 No. 11 November 2019: 2252-2271; MENGETAHUI PENGARUH KINERJA ISLAM TERHADAP MOTIVASI ISLAM, KOMITMEN ISLAM, DAN PELATIHAN ISLAM PADA KARYAWAN PT. ASURANSI TAKAFUL KELUARGA DI JAKARTA

\begin{tabular}{|c|c|c|c|}
\hline $\begin{array}{c}\text { Motivasi } \\
\text { Islam }\left(X_{1}\right)\end{array}$ & 0,965 & $<0,05$ & $\begin{array}{c}\text { Tidak } \\
\text { Signifikan }\end{array}$ \\
\hline $\begin{array}{c}\text { Komitmen } \\
\text { Islam }\left(X_{2}\right)\end{array}$ & 0,476 & $<0,05$ & $\begin{array}{c}\text { Tidak } \\
\text { Signifikan }\end{array}$ \\
\hline $\begin{array}{c}\text { Pelatihan } \\
\text { Islam }\left(X_{3}\right)\end{array}$ & 0,000 & $<0,05$ & Signifikan \\
\hline
\end{tabular}

Sumber: Hasil Penelitian, 2017 (diolah)

Dari hasil Uji $t$ pada Tabel 1. diketahui bahwa variabel motivasi Islam mempunyai nilai signifikansi sebesar 0,965 $>0,05$, sehingga dapat ditarik kesimpulan hipotesis pertama terkait variabel motivasi Islam ditolak. Maka, variabel motivasi Islam secara parsial tidak berpengaruh signifikan terhadap variabel kinerja Islam. Sedangkan variabel komitmen Islam mempunyai nilai signifikansi sebesar 0,476> 0,05 , sehingga dapat ditarik kesimpulan hipotesis pertama terkait variabel komitmen Islam ditolak. Maka, variabel komitmen Islam secara parsial tidak berpengaruh signifikan terhadap variabel kinerja Islam. Pada variabel pelatihan Islam mempunyai nilai signifikansi sebesar $0,000<0,05$, sehingga dapat ditarik kesimpulan hipotesis pertama terkait variabel pelatihan Islam diterima. Maka, variabel pelatihan Islam secara parsial berpengaruh signifikan terhadap variabel kinerja Islam.

Uji F

Tabel 2.

Hasil Uji Simultan (Uji F)

ANOVAa

\begin{tabular}{|c|c|c|c|c|c|}
\hline Model & Sum of & d & Mean & F & Sig. \\
& Square & f & Squar & & \\
& s & & e & & \\
\hline
\end{tabular}

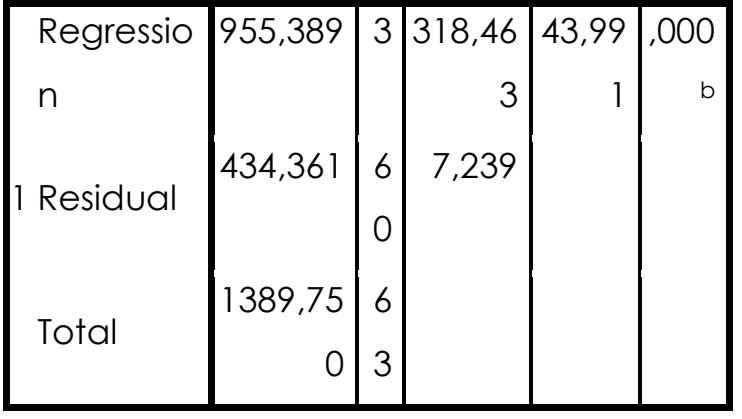

a. Dependent Variable: Kinerjalslam

b. Predictors: (Constant), Pelatihanlslam,

Motivasilslam, Komitmenlslam

Sumber: Hasil Penelitian, 2017 (diolah)

Uji ini berguna untuk melihat apakah variabel bebas motivasi Islam $\left(X_{1}\right)$, komitmen Islam $\left(\mathrm{X}_{2}\right)$, dan pelatihan Islam $\left(X_{3}\right)$ yang ada didalam model regresi linier berganda secara bersama mempengaruhi variabel terikat yaitu kinerja Islam (Y). Pada Tabel 4.23 dapat dilihat nilai signifikansi yang didapatkan yakni $0,000<0,05$. Maka, dapat ditarik kesimpulan bahwa variabel $X_{1}, X_{2}, X_{3}$ berpengaruh signifikan terhadap variabel terikat $Y$ dan hipotesis kedua diterima.

\section{Korelasi Berganda dan Determinasi \\ Berganda}

Tabel 3.

Hasil Uji Koefisien Determinasi

Model Summary

\begin{tabular}{|l|r|r|r|r|}
\hline Model & \multicolumn{1}{|c|}{$R$} & R Square & $\begin{array}{l}\text { Adjusted } \\
\text { R Square }\end{array}$ & $\begin{array}{c}\text { Std. Error } \\
\text { of the } \\
\text { Estimate }\end{array}$ \\
\hline 1 &, $829 a$ &, 687 &, 672 & 2,69060 \\
\hline
\end{tabular}

a. Predictors: (Constant), Pelatihanlslam,

Motivasilslam, Komitmenlslam

Sumber: Hasil Penelitian, 2017 (diolah)

Pada Tabel 3. diketahui nilai $R$ square sebesar 0,687 memperlihatkan bahwa secara bersama terdapat 
Anugrahadi, et al/Jurnal Ekonomi Syariah Teori dan Terapan Vol. 6 No. 11 November 2019: 2252-2271; MENGETAHUI PENGARUH KINERJA ISLAM TERHADAP MOTIVASI ISLAM, KOMITMEN ISLAM, DAN PELATIHAN ISLAM PADA KARYAWAN PT. ASURANSI TAKAFUL KELUARGA DI JAKARTA

pengaruh antara variabel bebas dengan variabel terikat. Kegunaan nilai $R$ square adalah untuk melihat tingkat ketepatan hubungan antara variabel bebas dan terikat dalam persamaan regresi.

Nilai $R$ square sebesar 0,687 menjelaskan bahwa pengaruh variabel terikat sebesar $68,7 \%$ sedangkan $31,3 \%$ dipengaruhi oleh variabel lain yang tidak termasuk dalam penelitian.

\section{Pembahasan}

Pengaruh motivasi islam terhadap kinerja islam

Hasil penelitian menunjukkan bahwa tidak berpengaruh signifikan antara variabel motivasi Islam terhadap kinerja Islam. Hal ini dibuktikan dengan hasil penelitian nilai signifikansi sebesar 0,965 lebih besar dari pada 0,05 dan dinyatakan hipotesis pertama ditolak, maka variabel motivasi Islam secara parsial tidak berpengaruh signifikan terhadap variabel kinerja Islam. Hal ini menunjukkan bahwa motivasi Islam yang terdapat pada karyawan tidak mempunyaipengaruh yang signifikan dalam meningkatkan dan menurunkan tingkat kinerja Islam.

Penelitian ini berbanding terbalik dengan jurnal yang dipakai oleh Gilang Meidizar yang menyatakan bahwa variabel motivasi itu terdapat pengaruh signifikan terhadap variabel kinerja pada PT. Primarindo Asia Infrastructure. Akan tetapi ada juga jurnal penelitian yang mengatakan bahwa motivasi itu tidak berpengaruhsignifikan terhadap kinerja hasil penelitian ini dilakukan oleh Yuli Suwati pada PT. Tunas hijau Samarinda.

Berdasarkan data penelitian yang diperoleh, diketahui sebagian besar responden menilai skor motivasi Islam berada pada kategori setuju dan sangat setuju tetapi tidak memberikan hasil yang signifikan. Ada beberapa penyebab kenapa motivasi Islam tidak berpengaruh signifikan terhadap variabel kinerja Islam pada PT. Asuransi Takaful keluarga Kantor Pusat Jakarta.

Pertama karyawan menganggap bahwa kewajiban dimuka bumi itu untuk mencari karunia Allah, dengan menjalankan perintah Allah salah satunya bekerja untuk mencari rezeki sendiri sudah menjalankan perintahnya. Kedua dorongan bekerja setiap orang berbedabeda, setiap orang memilik motif yang beraneka ragam saat ia melakukan sesuatu jika sesuatu sudah terpenuhi biasanya seseorang tersebut tidak terlalu mengejarnya, jika motifnya belum terpenuhi seseorang tersebut bakal mengejarnya terus.

Nabi Shallallahu 'alaihi wa sallam bersabda:

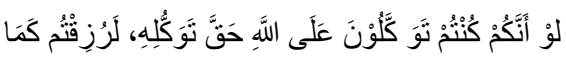

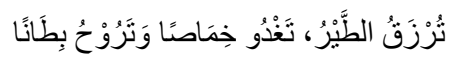

Laûannãkum tawã kullûna ala allahî hakka tawakkalihi laruzi kotum kama turzaku thoiru takdu jimasho wataruhu bitona.

Artinya: Sekiranya kalian bertawakkal kepada Allah dengan sebenar-benar tawakkal, niscaya Allah meberimu rizki 
Anugrahadi, et al/Jurnal Ekonomi Syariah Teori dan Terapan Vol. 6 No. 11 November 2019: 2252-2271; MENGETAHUI PENGARUH KINERJA ISLAM TERHADAP MOTIVASI ISLAM, KOMITMEN ISLAM, DAN PELATIHAN ISLAM PADA KARYAWAN PT. ASURANSI TAKAFUL KELUARGA DI JAKARTA

sebagaimana yang diberikanNya kepada burung-burung, berangkat pagi-pagi dalam keadaan lapar dan pulang sore hari dalam keadaan kenyang". (HR. Turmudzi) (Baqi, 2010:76)

Selanjutnya bekerja merupakan kewajiban untuk umat muslim untuk mencari rezeki contohnya jika bekerja keras akan mendapatkan rezeki yang banyak dan kalau tidak bekerja keras tidak dapat rezeki yang banyak, akan tetapi rezeki itu yang menentukkan adalah Allah, dengan begitu hakikat rezeki sebenarnya merupakan hubungannya dengan Allah. Seperti apa yang dikatakan dari para ahli tentang motivasi Islam dari Rahman (1995:13) yaitu terkait pekerjaan yang berasal dari hubungan seseorang dengan tuhannya. Seperti firman Allah SWT dalam surat Al Baqarah ayat 148 :

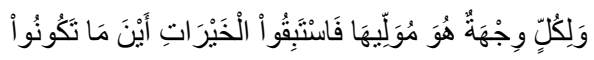

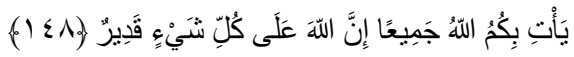

Wa li kulliw wijhatun huwa muwallîhã fastabiqul-khairãt, aina mã takûnû ya'ti bikumullãhu jamî'ã innallãha 'alã kulli syai'in qadî.

Artinya:Dan bagi tiap-tiap umat ada kiblatnya (sendiri) yang ia menghadap kepadanya. Maka berlomba-lombalah (dalam membuat) kebaikan. Di mana saja kamu berada pasti Allah akan mengumpulkan kamu sekalian (pada hari kiamat). Sesungguhnya Allah Maha Kuasa atas segala sesuatu. (QS Al Baqarah:148) (Depag RI, 2017)
Implementasi dari firman Allah tersebut yaitu sebagai hamba Allah yang mempunyai kewajiban untuk berlombalomba menuju kebaikan. Berlomba-lomba tersebut yang menyebabkan seseorang mempunyai semangat untuk melakukan kewajibannya yaitu bekerja. Dengan bekerja akan mencari Ridho Allah untuk mengharapkan rezeki. Kemungkinan dengan beberapa penyebab yang disebutkan. Hal ini yang menunjukkan bahwa motivasi Islam tidak berpengaruh pada kinerja Islam. Akan tetapi motivasi Islam dan kinerja Islam memiliki hubungan positif pada persamaan regresi dengan nilai sebesar 0,007, maksut dari nilai tersebut adalah jika motivasi Islam mengalami penurunan satu-satuan akan mengakibatkan penurunan nilai sebesar 0,007 terhadap kinerja Islam pada karyawan. Oleh sebab itu maka perusahaan lebih disarankan tetap menggunakan pegembangan variabel motivasi Islam terhadap karyawan perusahaan agar karyawan pada perusahaan PT. Asuransi Takaful Keluarga tetap memiliki nilai-nilai keislaman agar sesuai dengan visi dan misi lembaga keuangan syariah yang mengedepankan kuantitas dan kualitas sumber daya manusianya.

\section{Pengaruh komitmen islam terhadap kinerja islam \\ Hasil penelitian menunjukkan bahwa tidak berpengaruh signifikan antara variabel komitmen Islam terhadap kinerja Islam. Hal ini dibuktikan dengan}


Anugrahadi, et al/Jurnal Ekonomi Syariah Teori dan Terapan Vol. 6 No. 11 November 2019: 2252-2271; MENGETAHUI PENGARUH KINERJA ISLAM TERHADAP MOTIVASI ISLAM, KOMITMEN ISLAM, DAN PELATIHAN ISLAM PADA KARYAWAN PT. ASURANSI TAKAFUL KELUARGA DI JAKARTA

hasil penelitian nilai signifikansi sebesar 0,476 lebih besar dari pada 0,05 dan dinyatakan hipotesis pertama ditolak, maka variabel komitmen Islam secara parsial tidak berpengaruh signifikan terhadap variabel kinerja Islam. Hal ini menunjukkan bahwa komitmen Islam yang dimiliki oleh karyawan tidak mempunyai pengaruh yang signifikan dalam meningkatkan dan menurukan tingkat kinerja Islam.

Penelitian ini berbanding terbalik dengan jurnal yang dipakai yaitu jurnal dari Alfi (2015) yang menyatakan bahwa variabel komitmen itu terdapat pengaruh signifikan terhadap variabel kinerja pada karyawan PT. Bank Mandiri Area Cirebon. Akan tetapi ada juga penelitian yang mengatakan bahwa komitmen itu tidak berpengaruh signifkan terhadap kinerja. Hasil penelitian ini dilakukan oleh Liana (2015) pada guru SMA Kesatrian.

Berdasarkan data penelitian yang diperoleh, diketahui bahwa sebagian besar responden menilai skor komitmen Islam berada pada kategori setuju dan sangat setuju tetapi tidak memberikan hasil yang signifikan. Ada beberapa penyebab dengan hasil yang tidak berpengaruh signifikan antara variabel komitmen Islam terhadap kinerja Islam pada PT. Asuransi Takaful keluarga kantor Pusat Jakarta.

Pertama karyawan menganggap bahwa komitmen Islam terhadap organisasi atau perusahaan adalah suatu kewajiban yang seharusnya ada dikalangan karyawan dalam menjalankan tugas mereka sebagai sistem tersebut tidak membuat kinerja Islam mereka lebih tinggi. Kedua karyawan dalam bekerja seharusnya memiliki ikatan yang baik dalam melaksanakan tugasnya karena mereka menganggap hal tersebut adalah kewajiban yang seharusnya mereka lakukan sehungga tidak ada kaitan dengan kinerja Islam secara langsung.

Selanjutnya melihat dari tingkat usia responden persentase yang lebih tinggi yaitu umur yang berkisar 25-30 tahun, maka dengan hal ini kemungkinan karyawan untuk berkomitmen terhadap organisasi atau perusahaan masih tergolong rendah karena kemungkinan mereka masih ingin mencari pekerjaan lain yang dapat menunjang mereka dalam berkarir karena usia mereka masih sangat muda. Dari faktor lain dilihat dari lama bekerja responden dilihat dari hasil penelitian bahwa persentase paling tinggi yaitu lama bekerjanya masih dibawah 5 tahun, hal ini menunjukkan bahwa karyawan belum memiliki cukup pengalaman yang besar mengenai komitmen dalam bekerja. Kemungkinan dengan beberapa penyebab yang disebutkan hal ini yang menunjukkan bahwa komitmen Islam tidak berpengaruh pada kinerja Islam.

Sikap yang dilakukan oleh karyawan yang menganggap bahwa komitmen Islam terhadap organisasi atau perusahaan adalah suatu kewajiban juga 
Anugrahadi, et al/Jurnal Ekonomi Syariah Teori dan Terapan Vol. 6 No. 11 November 2019: 2252-2271; MENGETAHUI PENGARUH KINERJA ISLAM TERHADAP MOTIVASI ISLAM, KOMITMEN ISLAM, DAN PELATIHAN ISLAM PADA KARYAWAN PT. ASURANSI TAKAFUL KELUARGA DI JAKARTA

terdapat pada firman Allah surat $\mathrm{Adz}$ Dzariyaat ayat 56:

$$
\text { وَمَا خَلَقَتُ الْجِنَّ وَالْإِنسَ إِلَّا لِيَعْبُدُونِ (07) }
$$

Wamã khalaqtul-jinna wal-insa

illã liya'budûn.

Artinya:Dan aku tidak menciptakan jin dan manusia melainkan supaya mereka mengabdi kepadaku. (QS Adz Dzariyaat:56) (Depag RI, 2017)

Dalam riwayat Nabi Shallallahu 'alaihi wa sallam bersabda :

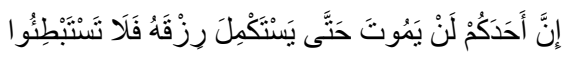

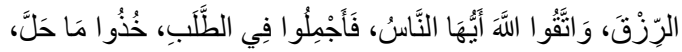

$$
\begin{aligned}
& \text { وَدَعُوْ ا مَا حَرَّمَهُ }
\end{aligned}
$$

Inna ahadakûm lan yamûtã hatta yastakmilã roẓkohu falã tastabthîu roẓku wattakuallah ayyûha annasû fajmila fitholabi khûdu ma khula wa daumãharo.

Artinya: Sesungguhnya salah seorang diantara kalian tidaklah meninggal sampai disempurnakan rezekinya, maka janganlah ia merasa lambat datang rezekinya. Bertakwalah kepada Allah wahai manusia, perbaikilah didalam mencari rezeki, ambil yang halal dan tinggalkan yang haram. (HR. Ibnu Hibban, Baihaqi dan selainnya, dishahihkan oleh Imam Al Albani) (Baqi, 2010:76).

Maksud dari hadist dan ayat $\mathrm{Al}$ Qur'an diatas menerangkan bahwa sebagai makhluk Allah harus mengabdi kepada sang pencipta, begitu juga dengan karyawan terhadap organisasinya. Implementasi tersebut seperti yang dianjurkan oleh rasullullah yaitu Hablum Minallah yang artinya hubungan antara manusia dengan Allah dan Hablum Minannas yang artinya manusia dengan manusia. Seperti halnya pendapat para pakar yaitu pendapat yang menyatakan komitmen Islam itu kewajiban, pendapat dari Amin (2010:120) menyatakan bahwa komitmen Islam merupakan kesediaan dan kerelaan bekerjanya dengan menepati segala ketentuan bekerja dalam ajaran agama. Begitu juga pendapatan Tasmara (2008:2) yang menyatakan bahwa seorang muslim harus menunjukkan sebagai orang yang amanah yang menunjukkan sikap pengabdian karena kehadirannya di dunia tidak lain untuk mengabdi. Walaupun komitmen Islam tidak berhubungan dengan kinerja islam akan tetapi perusahaan tetap menggunakan pendekatan secara islam karena dilihat dari persamaan regresinya memiliki hubungan positif yang sangat sedikit yaitu nilainya 0,149 jika motivasi mengalami peningkatan atau penurunan satu satuan akan mengamalami penurunan nilai pada kualitas dan kuantitas kinerja Islam pada karyawan dan sebagai perusahaan yang memiliki visi, misi dan citra sebagai lembaga keuangan syariah tetap lebih mengedepankan, pendekatan, dan pengembangan nilai-nilai secara islami.

Pengaruh pelatihan islam terhadap kinerja islam

Hasil penelitian menunjukkan bahwa terdapat pengaruh signifikan antara variabel pelatihan Islam terhadap kinerja Islam. Hal ini dibuktikan dengan hasil penelitian nilai signifikansi sebesar 0,000 lebih kecil dari pada 0,05 dan 
Anugrahadi, et al/Jurnal Ekonomi Syariah Teori dan Terapan Vol. 6 No. 11 November 2019: 2252-2271; MENGETAHUI PENGARUH KINERJA ISLAM TERHADAP MOTIVASI ISLAM, KOMITMEN ISLAM, DAN PELATIHAN ISLAM PADA KARYAWAN PT. ASURANSI TAKAFUL KELUARGA DI JAKARTA

dinyatakan hipotesis pertama diterima, maka variabel pelatihan Islam secara parsial berpengaruh signifikan terhadap variabel kinerja Islam.

Hal ini menunjukkan bahwa kemampuan pelatihan Islam yang dimiliki oleh karyawan mempunyai pengaruh yang signifikan dalam meningkatkan atau menurunkan tingkat kinerja Islam. Oleh karena itu dari ketiga variabel penelitian motivasi Islam, komitmen Islam, dan pelatihan Islam yang paling dominan terhadap kinerja Islam pada PT. Asuransi Takaful Keluarga di Jakarta yaitu pelatihan Islam.

Penelitian ini didukung hasil jurnal penelitian yang dilakukan oleh Anwar Prabu Mangkunegara dan Abdul Waris yang menghasilkan penelitian tentang variabel pelatihan terdapat pengaruh signifikan terhadap variabel kinerja, penelitian tersebut dilakukan pada PT. Asuransi Bangun Askrida.

Berdasarkan data penelitian yang diperoleh, bahwa sebagian besar responden menilai skor pelatihan Islam berada pada kategori setuju dan tidak setuju tetapi memberikan hasil yang signifikan dan berhubungan dengan kinerja Islam. Penelitian ini mendukung teori yang dikemukakan oleh Sumidjo yang (2015:30) yang menyatakan bahwa pelatihan itu memperbaiki penguasaan berbagai ketrampilan dan teknik pelaksanaan kerja tertentu, dengan proses yang berkelanjutan agar mendapatkan hasil yang semantap mungkin.

Untuk meminimalkan kekurangan yang ada pada diri karyawan yang dikarenakan kurangnya pengetahuan dan ketrampilan yang dimiliki, maka dengan adanya pelatihan Islam ini membantu karyawan untuk menambah ketrampilan mereka agar bisa meminimalkan masalah yang ada dengan cara yang diajarkan oleh Rasulullah. Dengan pelatihan Islam tersebut diharapkan karyawan mendapatkan tambahan pengetahuan dan ketrampilan agar kualitas dan kuantitas yang mereka miliki meningkat, dan akhirnya bisa mempengaruhi kinerja Islam mereka dalam bekerja. Oleh karena itu, program pelatihan Islam yang akan dilakukan pada karyawan harus dilaksanakan dengan baik dan benar, agar program yang dilakukan tepat sasaran dan bisa menambah ketrampilan karyawan dalam bekerja. Seperti firman Allah pada Surat An Nahl ayat 125 yang berbunyi:

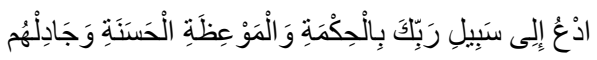

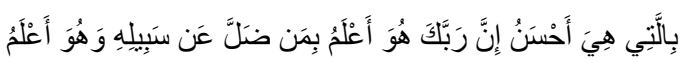

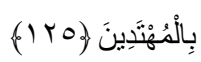

Ud'u ilã sabîli rabbika bil-hikmati walmau'izatil-ḥasanati wa jãdilhum bil-latî hiya ahsan, inna rabbaka huwa a'lamu bi man dalla 'an sabîlihî wa huwa a'lamu bilmuhtadîn.

Artinya:Serulah (manusia) kepada jalan Tuhan-mu dengan hikmah dan pelajaran yang baik dan bantahlah mereka dengan cara yang baik. Sesungguhnya Tuhanmu 
Anugrahadi, et al/Jurnal Ekonomi Syariah Teori dan Terapan Vol. 6 No. 11 November 2019: 2252-2271; MENGETAHUI PENGARUH KINERJA ISLAM TERHADAP MOTIVASI ISLAM, KOMITMEN ISLAM, DAN PELATIHAN ISLAM PADA KARYAWAN PT. ASURANSI TAKAFUL KELUARGA DI JAKARTA

Dialah yang lebih mengetahui tentang siapa yang tersesat dari jalan-Nya dan Dialah yang lebih mengetahui orangorang yang mendapat petunjuk. (QS An Nahl:125) (Depag Rl, 2017)

Maksud dari kutipan ayat tersebut menjelaskan bahwa manusia harus memiliki kuantitas dan kualitas baik dan benar, mereka harus diberi pelatihan Islam yang telah diajarkan oleh Rasulullah agar sesuai dengan apa yang diharapkan, dan menghasilkan tenaga kerja yang memiliki ketrampilan yang baik dan benar yang sesuai perspektif Islam.

\section{SIMPULAN DAN SARAN}

\section{Kesimpulan}

Berdasarkan hasil pengolahan data dalam penelitian ini, dapat ditarik simpulan sebagai berikut hasil pengujian secara parsial pada variabel motivasi Islam $\left(X_{1}\right)$ dan komitmen Islam $\left(X_{2}\right)$ tidak ada pengaruh terhadap kinerja Islam (Y). Sedangkan pada variabel pelatihan Islam $\left(X_{3}\right)$ ada pengaruh terhadap kinerja Islam (Y). Dari ketiga variabel tersebut yang berpengaruh secara dominan terhadap kinerja islam (Y) pada PT. Asuransi Takaful Keluarga di Kantor Pusat Jakarta yaitu variabel pelatihan Islam $\left(X_{3}\right)$.

Hasil pengujian secara simultan pada variabel motivasi Islam, komitmen Islam, dan pelatihan Islam berpengaruh signifikan terhadap kinerja Islam. Sedangkan Nilai $R$ square atau determinasi berganda adalah sebesar 0,687 yang menunjukkan bahwa $68,7 \%$ kinerja Islam dipengaruhi oleh ketiga variabel bebas, sedangkan $31,3 \%$ dipengaruhi oleh variabel lain yang tidak termasuk dalam penelitian.

hasil penelitian ini menghasilkan variabel motivasi Islam dan komitmen Islam tidak berpengaruh terhadap kinerja Islam sedangkan variabel pelatihan Islam berpengaruh terhadap kinerja Islam. Akan tetapi walaupun variabel motivasi Islam dan komitmen Islam tidak berpengaruh tapi memiliki hubungan yang positif dilihat dari nilai persamaan regresi walaupun nilainya sedikit. Dengan begitu pengembangan terhadap sumber daya manusia perspektif islam tetap dan terus dikembangkan oleh perusahaan agar karyawan memiliki nilai-nilai keislaman agar saat mereka bekerja mempunyai nilai kuantitas dan kualitas yang lebih dari karyawan yang tidak memiliki nilai islam yang dianjurkan oleh Rasulullah dan dari sumber-sumber Al Qur'an maupun Al Hadist.

\section{Saran}

1. Bagi Perusahaan Asuransi Takaful Keluarga Kantor Pusat Jakarta Hasil penelitian ini diharapkan dapat dijadikan sebagai bahan masukan Lembaga Keuangan yang berbasis Syariah, pertimbangan dalam pengambilan keputusan khususnya terkait dengan motivasi Islam, Komitmen Islam, dan Pelatihan Islam yang akan berdampak baik secara langsung atau tidak langsung kepada karyawan nantinya diharapkan dapat bekerja sesuai dengan kinerja Islam 
Anugrahadi, et al/Jurnal Ekonomi Syariah Teori dan Terapan Vol. 6 No. 11 November 2019: 2252-2271;

MENGETAHUI PENGARUH KINERJA ISLAM TERHADAP MOTIVASI ISLAM, KOMITMEN ISLAM, DAN PELATIHAN

ISLAM PADA KARYAWAN PT. ASURANSI TAKAFUL KELUARGA DI JAKARTA

mereka akan berdampak pada pekerjaan karyawan. Wajib hukumnya juga bahwa lembaga kevangan syariah mengedepankan, pendekatan, dan pengembangan terhadap sumber daya yang dimiliki dengan nilai-nilai Islam agar nantinya kuantitas dan kualitas sumber daya yang dimiliki berbeda dengan yang tidak memiliki nilai-nilai keislaman yang sudah dijelaskan dan dilakukan oleh Rasulullah melalui Al hadist dan Al Qur'an. Sedangkan untuk sistem perekrutan karyawan diusahakan merekrut karyawan-karyawan yang kompeten dibidangnya yaitu bidang ekonomi dan bidang syariah agar sesuai dengan tujuan dari perusahaan yang berjalan di sektor syariah agar nantinya kuantitas dan kualitasnya sudah sesuai dengan nilai-nilai syariah.

2. Bagi Penelitian Selanjutnya

Penelitian ini dapat digunakan sebagai bahan pertimbangan untuk melakukan penelitian selanjutnya, sebab dalam penelitian ini diperoleh nilai $R$ square sebesar $68,7 \%$ sedangkan $31,3 \%$ yang merupakan variabel lain yang tidak diteliti dalam penelitian ini yang mempengaruhi motivasi Islam, komitmen Islam, dan pelatihan Islam terhadap kinerja Islam sehingga disarankan bagi peneliti lain untuk menambah variabel-variabel sumber daya manusia yang lainnya dan menggunakan alat penelitian statistika yang lainnya yaitu menggunakan analisis jalur (Path Analysis) dan analisis SEM (Structural Equation Modeling) agar mendapatkan pengembangan atau nilai-nilai yang belum tersampaikan oleh peneliti.

3. Bagi Masyarakat

Dengan menerapkan model motivasi Islam, komitmen Islam, dan pelatihan Islam, apabila nilai-nilai Islami tersebut diimplementasikan dalam perusahaan, kehidupan, dan pemerintahan maka sifat-sifat yang dicerminkan oleh Rasulullah dapat dimiliki semua orang.

4. Keterbatasan Penelitian

Dalam penelitian ini, peneliti menggunakan angket kuesioner yang dibuat oleh peneliti sebagai alat ukur, sehingga menurut peneliti tidak begitu efesien karena hasil angket yang didapat hanya persepsi saja. Diharapkan pada penelitian mendatang dapat menggunakan angket yang lainnya yang disediakan atau dibuat oleh perusahaan atau organisasi dengan melihat kondisi dilapangan yang diperlukan oleh perusahan tersebut, sehingga obyektifitasnya dapat teruji dan terukur dengan baik sesuai yang diharapkan oleh perusahaan atau organisasi.

\section{DAFTAR PUSTAKA}

Anwar Prabu Mangkunegara dan Abdul Waris. 2015. Effect of Training, Competence, and Discipline on Employee Performance in Company (Case Study in PT. Asuransi Bangun Askrida). 2nd 
Anugrahadi, et al/Jurnal Ekonomi Syariah Teori dan Terapan Vol. 6 No. 11 November 2019: 2252-2271; MENGETAHUI PENGARUH KINERJA ISLAM TERHADAP MOTIVASI ISLAM, KOMITMEN ISLAM, DAN PELATIHAN ISLAM PADA KARYAWAN PT. ASURANSI TAKAFUL KELUARGA DI JAKARTA

Global Conference on Business

and Social Science-2015, GCBSS-

2015, 17-18 September 2015, Bali, Indonesia , 8.

Rahman, Abdel Rahman AA. 1995. An

Islamic Perpective On

Organizational Motivation. The american journal of Islamic social science vol 12 no 2.

Sugiyono. 2012. Metode Penelitian Kuantitatif Kualitatif dan R\&D. Bandung:Alfabeta.

Suparyadi.2015. Manajemen Sumber Daya Manusia, Menciptakan Keunggulan Bersaing Berbasis SDM. Kediri:Andi

Tasmara, Toto. 2008. Membudayakan Ełos Kerja Islami. Jakarta: Gema Insani.

Zadjuli. 2004. Etika Sebagai Landasan Moral Pembangunan Ekonomi Di Indonesia. 